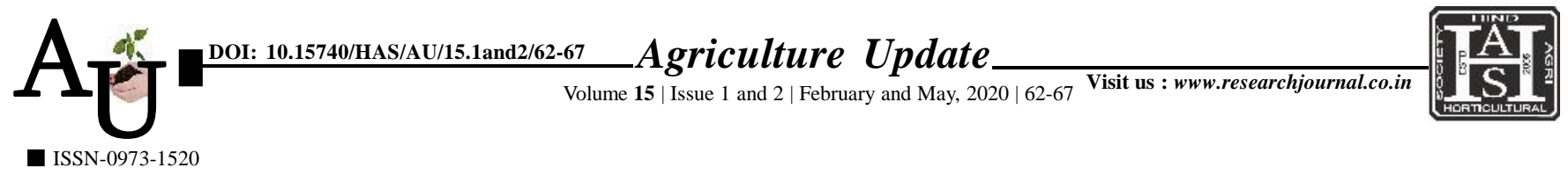

\title{
Rевевсн Aвтіск: Problems faced by Anna bhagya beneficiaries and the suggestion given by them for improvement of Anna bhagya scheme
}

\author{
Geeta P. Channal, Shobha Nagnur, Supriya P. Patil and Rekha Rayangoudar
}

Article Chronicle:

Received :

12.02.2020;

Revised :

07.04.2020;

Accepted :

15.04.2020

KEY WoRDS:

Anna bhagya yojana,

Food security, Public

distribution system

(PDS)

SUMMARY : Food security exists when all people, at all times, have physical and economic access to sufficient, safe and nutritious food to meet their dietary needs and food preferences for an active and healthy life. The Public Distribution System is one of the poverty alleviation programmes in India. The basic aim of PDS is to provide essential commodities like rice, wheat, sugar, edible oil and kerosene at subsidized prices throughout the country. In our investigation we studied the problems faced by Anna bhagya scheme beneficiaries in Karnataka state. The study was carried out during 2018-19 in seven districts of Northern Karnataka namely Dharwad, Uttar Kannada, Bagalkot, Vijayapura, Haveri, Belagavi and Gadag. From each districts 20 beneficiaries were selected making the sample size of 140. Simple random sampling technique was used to select the respondents. Pre-tested interview schedule was used to collect the data and suitable statistical tools like frequency and percentages were used for analysis of the data. It was noticed from the study that, cent per cent of the beneficiaries never faced problems like that they should pay for some items and compulsory purchase of some items. It was also clear from the study that, 84.29 per cent of the beneficiaries never mentioned about the leakages of food grains and the weight of the food items.

How to cite this article : Channal, Geeta P., Nagur, Shobha, Patil, Supriya P. and Rayangoudar, Rekha (2020). Problems faced by Anna bhagya beneficiaries and the suggestion given by them for improvement of Anna bhagya scheme. Agric. Update, 15(1 and 2): 62-67; DOI : 10.15740/HAS/AU/15.1and2/62-67. Copyright@ 2020: Hind Agri-Horticultural Society.

Author for correspondence :

Geeta P. Channal

AICRP (HE), University

of Agricultural Sciences,

Dharwad (Karnataka)

India

Email: geetrajpatil@

yahoo.co.in

See end of the article for

authors' affiliations 